\title{
Pondering the atypicality of ARDS in COVID-19 is a distraction for the bedside doctor
}

\author{
Martin J. Tobin * (1)
}

(c) 2021 The Author(s)

I read with interest the editorial by Goligher et al. "Is severe COVID-19 pneumonia a typical or atypical form of ARDS? And does it matter?" [1]. The editorialists address the first question with a thoughtful analysis, but their answer to the second question comes up short.

The corollary to the second question is "To whom does it matter?" The question about atypicality matters to researchers who are rightfully probing the quandaries fomented by the pandemic. For clinicians, however, mulling over this question is a distraction. The critical dilemma for the bedside doctor facing a seriously ill patient affected by coronavirus disease 2019 (COVID-19) is: "To be, or not to be (intubated), that is the question" (with amends to Hamlet) [2]. Thinking about the atypicality of acute respiratory distress syndrome (ARDS) in COVID-19 is to sprinkle additional chaff where a clinician is scouring for the wheat that will resolve the intubation dilemma [3].

The sole ventilator setting in patients with ARDS proven to influence survivability is avoidance of tidal volume of $12 \mathrm{ml} / \mathrm{kg}$. Since tidal volume $12 \mathrm{ml} / \mathrm{kg}$ is not used in any patient, making a diagnosis of ARDS does not impact the selection of any ventilator setting [3]. A diagnosis of ARDS does not matter to the bedside doctor caring for a COVID-19 patient. Despite other writings of the editorialists asserting that tidal volume $6 \mathrm{ml} / \mathrm{kg}$ represents standard care, there are no data to say that $6 \mathrm{ml} /$ $\mathrm{kg}$ is superior to $11 \mathrm{ml} / \mathrm{kg}$ (or anything in between) [3].

Goligher et al. enjoin clinicians "to follow the accepted evidence-based framework for the management of

\footnotetext{
*Correspondence: mtobin2@lumc.edu

Division of Pulmonary and Critical Care Medicine, Hines Veterans Affairs Hospital and Loyola University of Chicago Stritch School of Medicine,
} Hines, IL 60141, USA
ARDS." That was the approach of one ARDS-Network center, where patients with COVID-19 were "managed with mechanical ventilation and established ARDS protocols." Analyzing the reported data, Yaroshetskiy et al. [4] asked why so many of the COVID-19 patients with relatively mild physiological abnormalities were ever intubated.

With COVID-19, a generation of doctors nurtured on protocols and guidelines were left in the lurch when they faced an onslaught of patients requiring decisions based on clinical judgment [2]. The hope of being able to offload responsibility to an external, self-interpreting, authoritative resource is a centuries' old dream. Even in laboratory science, however, the most critical steps ultimately demand subjective judgments (the choice of transducer, positioning of tangents, and so on).

Evidence-based guidelines can never help a doctor resolve whether a patient is best managed by inserting an endotracheal tube or avoiding its use. That decision is based on clinical judgment, gestalt, and tacit knowledge [2]. I agree with Gattinoni that ventilator management is an important consideration in explaining the "dramatically different outcomes (20-80\% mortality rates)" for patients with "an identical disease."[5] Emerging data reveal a $41.9 \%$ decrease in the rate of endotracheal intubation between February-March and April-May, accompanied by a $20.9 \%$ decrease in 28 -day mortality [6]. In science, arriving at answers is frequently less fructiferous than posing the right question. For bedside care of COVID-19 patients, asking whether to intubate or not intubate is the lynchpin-and pondering the atypicality of ARDS is best eschewed [3]. 


\section{Compliance with ethical standards}

\section{Conflicts of interest}

MJT receives royalties for two books on critical care published by McGraw-Hill, Inc., New York.

\section{Open Access}

This article is licensed under a Creative Commons Attribution-NonCommercial 4.0 International License, which permits any non-commercial use, sharing, adaptation, distribution and reproduction in any medium or format, as long as you give appropriate credit to the original author(s) and the source, provide a link to the Creative Commons licence, and indicate if changes were made. The images or other third party material in this article are included in the article's Creative Commons licence, unless indicated otherwise in a credit line to the material. If material is not included in the article's Creative Commons licence and your intended use is not permitted by statutory regulation or exceeds the permitted use, you will need to obtain permission directly from the copyright holder. To view a copy of this licence, visit http://creativecommons.org/licen ses/by-nc/4.0/.

\section{Publisher's Note}

Springer Nature remains neutral with regard to jurisdictional claims in published maps and institutional affiliations.

Accepted: 21 December 2020

Published online: 15 January 2021

\section{References}

1. Goligher EC, Ranieri VM, Slutsky AS (2020) Is severe COVID-19 pneumonia a typical or atypical form of ARDS? And does it matter? Intensive Care Med 25:1-3. https://doi.org/10.1007/s00134-020-06320-y

2. Tobin MJ (2020) The criteria used to justify endotracheal intubation of patients with COVID-19 are worrisome. Can J Anaesth. https://doi. org/10.1007/s12630-020-01853-8

3. Tobin MJ (2020) Does making a diagnosis of ARDS in patients with coronavirus disease 2019 matter? Chest 158:2275-2277. https://doi. org/10.1016/j.chest.2020.07.028

4. Yaroshetskiy Al, Avdeev SN, Konanykhin VD (2020) Acute respiratory distress syndrome in COVID-19: do all these patients definitely require intubation and mechanical ventilation? Am J Respir Crit Care Med 202:1480-1481. https://doi.org/10.1164/rccm.202007-2713LE

5. Gattinoni L, Busana M, Camporota L, Marini JJ, Chiumello D (2020) COVID19 and ARDS: the baby lung size matters. Intensive Care Med 4:1-2. https ://doi.org/10.1007/s00134-020-06324-8

6. Doidge JC, Mouncey PR, Thomas K, Gould DW, Ferrando-Vivas P, Shankar-Hari M, Harrison DA, Rowan KM (2020) Trends in intensive care for patients with COVID-19 in England, Wales and Northern Ireland. Am J Respir Crit Care Med. https://doi.org/10.1164/rccm.202008-32120C 